\title{
A Hydroponics Assay Distinguishes between $S$-metolachlor-tolerant and -sensitive Sweetpotato Cultivars
}

\author{
Matthew A. Cutulle, H. Tyler Campbell, and Monica Farfan \\ Clemson University, Coastal Research and Education Center, 2700 Savannah \\ Highway, Charleston, SC 29414
}

Phillip A. Wadl

U.S. Department of Agriculture, Agricultural Research Service, U.S. Vegetable Laboratory, 2700 Savannah Highway, Charleston, SC 29414

Additional index words. herbicide, vegetable breeding, xenobiotic screening

\begin{abstract}
Weed management is an important component of sweetpotato production. Currently, $S$-metolachlor is the only herbicide registered in sweetpotato that has some suppressive effect on nutsedge species (Cyperus spp.). It is integral that the release of any new germplasm from sweetpotato breeding programs be tolerant to $S$-metolachlor. Screening for thousands of experimental clones for $S$-metolachlor in a field trial would be cumbersome. Therefore, screening for tolerant lines might be streamlined in an hydroponics system. Research was conducted to determine whether a hydroponics assay could detect differences in $S$-metolachlor response between a known sensitive sweetpotato cultivar (Centennial) and a tolerant sweetpotato cultivar (Beauregard) in 10 days. Results of the study show that 'Beauregard' was $\approx 50$ times more tolerant to $S$-metolachlor than 'Centennial' when accessing injury at the $25 \%$ threshold. No differences were detected in $\boldsymbol{S}$-metolachlor response between cultivars in the soil-based assay. This assay could be used for screening for $S$-metolachlor tolerance in a sweetpotato breeding program.
\end{abstract}

Sweetpotato is an important specialty crop in the United States (Wadl et al., 2018). After many years of decline beginning in the 1950s, per-capita U.S. consumption of sweetpotatoes has shown a dramatic increase during the past 10 years, and production levels have increased to a level not seen since the 1940s. Nationally, sweetpotato production increased by $37.6 \%$ from 2012 to 2017 - by far the biggest jump of any vegetable crop (U.S. Department of Agriculture, 2019; Washington Post, 2019). These gains have been the result of new cultivars, better management practices, and increased industry/consumer demand for more nutritious foods, including a wide range of value-added products. The economic viability of sweetpotato production can be undermined as a result of the susceptibility of commercial varieties to biotic (e.g., diseases, insect pests, weeds) and abiotic (e.g., environment variability, low fertility) factors that can dramatically influence yield, quality, and marketability of the harvested storage roots. Effectively managing weeds is a top priority for sweetpotato growers.

Three weeds that are of primary concern to sweetpotato producers in the Carolinas are

Received for publication 14 Feb. 2020. Accepted for publication $20 \mathrm{Apr}$. 2020.

Published online 21 May 2020

M.A.C. is the corresponding author. E-mail: mcutull@ clemson.edu.

This is an open access article distributed under the CC BY-NC-ND license (https://creativecommons. org/licenses/by-nc-nd/4.0/). yellow nutsedge (Cyperus esculentus L.), purple nutsedge (Cyperus rotundus L.), and Palmer amaranth (Amaranthus palmeri S. Watts). Yellow and purple nutsedge affect sweetpotato yield and quality negatively, and are the most difficult-to-control weeds in sweetpotato across the Southeast because of the high rainfall experienced during the growing season. In Mississippi, Meyers and Shankle (2015) reported that yellow nutsedge densities of 5 to 90 shoots $/ \mathrm{m}^{2}$ of planted sweetpotato row resulted in yield losses of $18 \%$ to $96 \%$ depending on grade. A single nutsedge shoot at 2 weeks after transplanting can increase 7.6 times by the end of the season, resulting in exponential asexual reproduction of this troublesome weed (Meyers and Shankle, 2015). In addition to reducing yield, nutsedge roots, rhizomes, shoots, and tubers grow into and through sweetpotato storage roots, resulting in storage roots being marketed for processing instead of fresh consumption, at an $80 \%$ decrease in value to the producer. Palmer amaranth is the most competitive weed and is the driving force for weed management programs in North Carolina and South Carolina. It can easily exceed sweetpotato height within $10 \mathrm{~d}$ after transplanting and ultimately reaches heights greater than $6 \mathrm{ft}$ and spreads to nearly $5 \mathrm{ft}$ wide (Meyers et al., 2010). As a result, the weed can block up to $82 \%$ of available light from reaching the sweetpotato crop and decreases marketable yield by $85 \%$ (Meyers et al., 2010). Simply leaving palmer amaranth in the field for 2 weeks can result in a 5\% reduction of marketable sweetpotato yield (Smith et al., 2020).
To manage weeds, sweetpotato growers use herbicides, between-row cultivation, mowing, and hand removal. Currently, 10 herbicides are registered for managing weeds in season (Kemble, 2020). Those commonly used are flumioxazin, $S$-metolachlor, clomazone, and two graminicides (sethoxydim and clethodim). Although napropamide and dimethyl tetrachloroterephthalate are registered for sweetpotato, they provide inconsistent and often inadequate weed control (Weir, 2001). $S$-metolachlor can provide excellent pigweed control if applied and activated before weed emergence. Also, it is the only herbicide registered in sweetpotato that can provide yellow nutsedge suppression. However, producers are reluctant to apply $S$-metolachlor at transplanting, citing concerns that it results in misshapen storage roots of some cultivars (Meyers et al., 2012; Personal communication with multiple growers in South Carolina). It has been well documented that delaying application of $S$-metolachlor until $10 \mathrm{~d}$ after transplanting can reduce some of the injury (Meyers et al., 2012). Optimizing application timing of $S$-metolachlor, as well as identification of cultivars that are tolerant to the effects of $S$-metolachlor, are critical to weed suppression in Southeast sweetpotato production.

The identification and selection of $S$ metolachlor-tolerant plants is a priority for sweetpotato breeders. $S$-metolachlor is the only herbicide registered in sweetpotato for suppression of yellow nutsedge and it provides excellent control of pigweed species; therefore, it is important for sweetpotato growers in the Southeast to plant sweetpotato cultivars that have tolerance to $S$-metolachlor (Meyers and Shankle, 2017). In vitro methods are efficient for screening stress tolerance in different plants, demanding lower resources, materials, and time than field trials (Sakhanokho and Kelley, 2009). Hydroponics has been used to access herbicide tolerance or resistance in weeds (Brosnan et al., 2014; Cutulle et al., 2009). In our study, research was conducted to determine whether a hydroponics screening with $S$ metolachlor could discriminate between a known $S$-metolachlor-sensitive cultivar and a cultivar that is known to be tolerant to the herbicide.

\section{Materials and Methods}

\section{Plant propagation}

Hydroponics. Based on screening from the U.S. Department of Agriculture (USDA) sweetpotato germplasm collection and other studies, 'Beauregard' [USDA-Agricultural Research Service (ARS), Sweetpotato Breeding Program, Charleston, SC] has a greater inherent tolerance to applications of $S$-metolachlor than 'Centennial' (USDA-ARS, Sweetpotato Breeding Program, Charleston, SC) (Meyers et al., 2010). Eighty slips each of 'Beauregard' and 'Centennial' were harvested from $\approx 2$-month-old vines in a field setting at the USDA-ARS, U.S. Vegetable Laboratory in Charleston, SC (USVL; $32.796919,-80.063104)$. Slips were then cut 
to $\approx 20 \mathrm{~cm}$, defoliated to three to five leaves, and transplanted immediately into raised beds that contained native soil and were maintained $(7 \mathrm{~d})$ in the greenhouse under natural light at $\approx 30{ }^{\circ} \mathrm{C} / 25^{\circ} \mathrm{C}$ day/night until transplanted into the hydroponic system on 10 Oct. 2017. The experiment was repeated on 10 Nov. 2017.

For the hydroponic system, rubber tubs (Rubbermaid Roughneck; Rubbermaid Commercial Products LLC, Winchester, VA) with a volume of $\approx 11 \mathrm{~L}$ were filled with $2 \mathrm{~L} 1.4 \%$ Hoagland solution (Hoagland and Arnon, 1950). Each tub was connected to an air blower (model SST30; Sweetwater, Ft. Collins, $\mathrm{CO}$ ) via polyvinylchloride (PVC) piping and connectors with a $2.54-\mathrm{cm}$ internal diameter (Home Depot, Atlanta, GA), vinyl tubing (B\&K LLC, Memphis, TN; and Everbilt, Home Depot, Atlanta, GA), and finally to an air stone (model ALR8, Sweetwater) to oxygenate the nutrient solution. Barbed adapters (Sharkbite, Atlanta, GA) were used to connect the vinyl tubing and PVC piping.

Two 1-cm-diameter holes were drilled into the lid of each tub. One slip was inserted into each hole and was secured using a grafting clip (Botou Yongchuang Spring Manufacturing Co., Ltd., Hebei, China), with each tub containing two slips of the same variety. A modified Hoagland solution was mixed in a $200-\mathrm{L}$ drum and then $2 \mathrm{~L}$ of the solution was transferred to each tub. Pictures of the hydroponics setup are noted in Fig. 1.

Greenhouse soil bioassay. Twenty slips each of the commercial sweetpotato varieties 'Beauregard' and 'Centennial' were harvested from $\approx 2$-month-old vines in a field setting at the USDA Vegetable Laboratory in Charleston, SC. Slips were then cut to $\approx 20 \mathrm{~cm}$, defoliated to three to five leaves, and transplanted immediately into native soil in $10-\mathrm{cm}$ square plots (black form plots; Greenhouse Megastore, Danville, IL) The soil type was Yonges fine silty sand, the $\mathrm{pH}$ was 6.3 , and the organic matter content was less than $0.5 \%$. The soil was collected from the organic section of the Clemson Coastal Research and Education Center (32.792968, -80.069748). Seven days later, the herbicide treatments were applied postemergently.

\section{Herbicide application}

Hydroponics bioassay. A factorial experimental design was used with increasing logarithmic rates of $S$-metolachlor $(0,0.01$, $0.1,1$, and $10 \mathrm{~mm}$ ) applied to each of two varieties ('Beauregard' and 'Centennial'). The experimental unit consisted of a tub with two sweetpotato slips. The experiment was conducted as a randomized complete block design with four replications. $S$-metolachlor was added to the solution using plastic syringes (Henke Sass Wolf, Tuttlingen, Germany) $1 \mathrm{~d}$ after the slips were secured to the tubs.

Greenhouse soil bioassay. A factorial experimental design was used with four $S$ metolachlor treatments of increasing logarithmic rates $(0,10,100$, and $1000 \mathrm{~g}$ a.i./ha) applied to each of two varieties ('Beauregard' and 'Centennial'). The experiment was conducted as a randomized complete block design with four replications. The treatments were applied at $200 \mathrm{~L} /$ ha with water as a carrier to sweetpotatoes $10 \mathrm{~d}$ after transplanting using a carbon dioxide-powered backpack sprayer with 8002 flat fan nozzles.

\section{Data analyses}

Percent crop injury, root length (in centimeters), and total fresh weight (in grams) were measured for each slip in each tub $10 \mathrm{~d}$ after the $S$-metolachlor applications in the hydroponics assay. Percent crop injury was recorded in the soil-based bioassay $10 \mathrm{~d}$ after treatment. Crop injury was rated on a $0 \%$ to $100 \%$ scale, with a rating of $100 \%$ indicating a dead plant whereas a rating of $0 \%$ indicates no injury.

Data were analyzed with analysis of variance $(\alpha=0.05)$ using a mixed-model methodology (JMP Pro 12; SAS Institute Inc., Cary, NC) for each response variable according to the full factorial experiment design, with herbicide concentration, variety, and trial run considered fixed whereas replication was considered random. Means were separated according to Tukey's honestly significant difference test. Data taken with regard to percent phytotoxicity were fit to a doseresponse curve with a five-parameter log- logistic model (Gottschalk and Dunn, 2005; Seefeldt et al., 1995):

$$
y=c+\frac{d+c}{1+\exp [-a(\text { Herbicide }-b)]^{f}} .
$$

The model was used to calculate the lethal dose (LD) of $S$-metolachlor to elicit phytotoxicity by $25 \%\left(\mathrm{LD}_{25}\right)$ and $50 \%\left(\mathrm{LD}_{50}\right)$ where $y$ is the herbicide dose necessary to cause the predicted injury, $c$ is the asymptote for low doses, $c$ is the asymptote for high doses, $a$ is the slope parameter, $b$ is the inflection point, and $f$ is the symmetrical power. The upper asymptote is the point of the growth curve that represents the maximum of the parameter measured. The lower asymptote is the point of the growth curve that represents the minimum of the parameter measured (Paine et al., 2012). Trial run did not have a significant effect on any of the variables, thus data are pooled across both trials.

\section{Results}

Hydroponics bioassay. The rate-response trials confirmed that 'Beauregard' was more tolerant to $S$-metolachlor than 'Centennial'. 'Centennial' exhibited significantly $(P<$ 0.05 ) greater injury at $0.01,1.0$, and $10.0 \mathrm{~mm}$ (Table 1). The discriminatory dose regarding
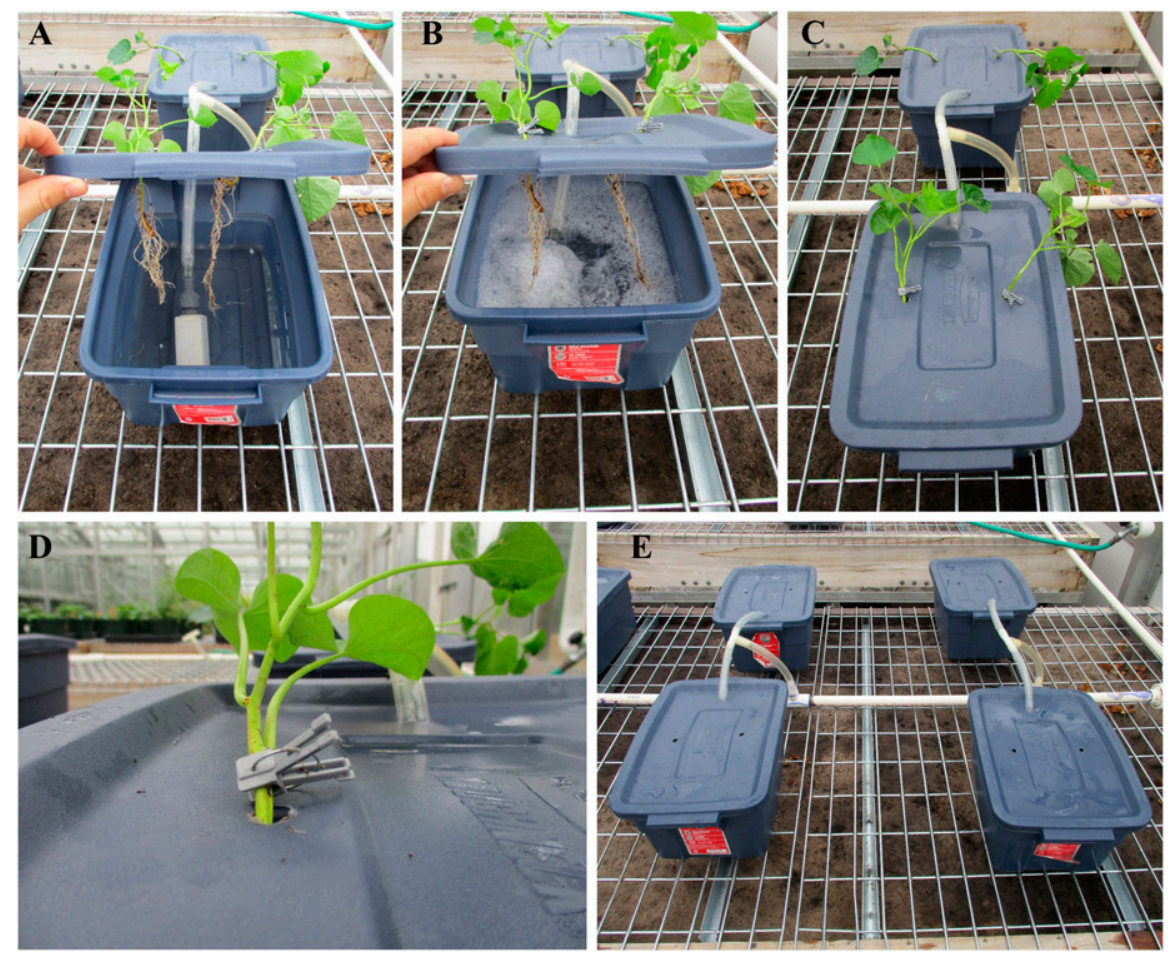

Fig. 1. (A) Sweetpotato roots shown hanging through the lid of a hydroponic container with the air blower powered off. The lowest growing point on the stem of each slip was submerged in solution at a depth of $\approx 1.2$ to $5 \mathrm{~cm}$. (B) Sweetpotato roots shown hanging through the lid of a hydroponic container with the air blower powered on. The lowest growing point on the stem of each slip was submerged in solution at a depth of $\approx 1.2$ to $5 \mathrm{~cm}$. (C) Sweetpotato slips shown with the grafting clip attached where roots are suspended in solution within the container. Foliage sits outside of the upper side of the container. (D) Sweetpotato slip shown with grafting clip attached. The grafting clip ensures the slip does not fall farther into the hydroponic solution. (E) Hydroponic containers shown with the main air-supplying line running in the center of two lines of tubs. Vinyl tubing attached to the main air-supplying line and then subsequently to two air stones, one within each container, aerates the solution within each container. 
$S$-metolachlor screening could be $1.0 \mathrm{~mm}$, where 'Beauregard' exhibited $30 \%$ crop injury and 'Centennial' was injured more than $80 \%$. There was no significant difference at $0.1 \mathrm{~mm}$.

When extrapolating a dose response for both cultivars, the amount of herbicide required to cause $25 \%$ injury was 11 times for 'Beauregard' when compared with 'Centennial' averaged across both trials. Furthermore, the amount of herbicide required to cause $50 \%$ injury in 'Beauregard' was $1.72 \mathrm{~mm}$ whereas the amount required to injure 'Centennial' $50 \%$ was $0.067 \mathrm{~mm}$ (Table 2 ).

The interaction between cultivar and herbicide dose was significant $(P=0.03)$ regarding maximum root length measurements taken $10 \mathrm{~d}$ after transplanting. With no herbicide present, maximum root length for 'Beauregard' was $12.5 \mathrm{~cm}$ whereas 'Centennial' was $\approx 10.0 \mathrm{~cm}$ (Table 3 ). There was no significant decrease in maximum root length for either cultivar until $1.0 \mathrm{~mm}$, when maximum root length was $13.0 \mathrm{~cm}$ for 'Beauregard', and 'Centennial' root length was $9.0 \mathrm{~cm}$.

Table 1. Impact of herbicide rate on two sweetpotato cultivars relative to the nontreated check taken $10 \mathrm{~d}$ after transplanting in the hydroponics assay.

\begin{tabular}{llc}
\hline Herbicide rate $(\mathrm{mm})$ & Cultivar & Percent injury $^{\mathrm{z}}$ \\
\hline 0.01 & Centennial & $23 \mathrm{~d}$ \\
0.01 & Beauregard & $5 \mathrm{e}$ \\
0.1 & Centennial & $35 \mathrm{~d}$ \\
0.1 & Beauregard & $25 \mathrm{~d}$ \\
1.0 & Centennial & $88 \mathrm{~b}$ \\
1.0 & Beauregard & $30 \mathrm{~d}$ \\
10 & Centennial & $97 \mathrm{a}$ \\
10 & Beauregard & $75 \mathrm{c}$ \\
\hline
\end{tabular}

${ }^{\mathrm{z}}$ Mean separation using Tukey's test $(P \leq 0.05)$. Means within a column followed by the same letter grouping are not significantly different.

Table 2. Predicted values of $S$-metolachlor required to cause $25 \%$ and $50 \%$ injury in 'Beauregard' and 'Centennial' sweetpotato in the hydroponic assay.

\begin{tabular}{lcc}
\hline Cultivar & $\mathrm{ED}_{25}(\mathrm{~mm})$ & $\mathrm{ED}_{50}(\mathrm{~mm})$ \\
\hline Beauregard & 0.779 & 1.723 \\
Centennial & 0.014 & 0.067 \\
\hline
\end{tabular}

ED refers to the effective dose in mu required to cause a specific amount of injury: $25 \%$ or $50 \%$ in this analysis.

Table 3. Impact of herbicide rate on root length of two sweetpotato cultivars taken $10 \mathrm{~d}$ after transplanting in the hydroponics assay.

\begin{tabular}{llc}
\hline Herbicide rate $(\mathrm{mm})$ & Cultivar & Root length $(\mathrm{cm})^{\mathrm{z}}$ \\
\hline 0 & Centennial & $10.0 \mathrm{~b}$ \\
0 & Beauregard & $12.5 \mathrm{ab}$ \\
0.01 & Centennial & $10.5 \mathrm{~b}$ \\
0.01 & Beauregard & $12.0 \mathrm{ab}$ \\
0.1 & Centennial & $10.0 \mathrm{~b}$ \\
0.1 & Beauregard & $12.5 \mathrm{ab}$ \\
1.0 & Centennial & $9.0 \mathrm{~b}$ \\
1.0 & Beauregard & $13.0 \mathrm{a}$ \\
10 & Centennial & $8.0 \mathrm{c}$ \\
10 & Beauregard & $9.0 \mathrm{bc}$ \\
\hline
\end{tabular}

${ }^{\mathrm{z}}$ Mean separation using Fisher's protected least significant difference test $(P \leq 0.05)$. Means within a column followed by the same letter grouping are not significantly different.
Herbicide treatment did not have a significant effect $(P=0.12)$ on fresh weight, as there was a lot variability in the size of the foliage from plant to plant (Table 4). The lesions, necrosis, and chlorosis present on the plants appeared to be negligible regarding fresh weight totals.

Greenhouse soil bioassay trial. Only the main effect of herbicide rate was significant for herbicide injury $(P=0.001)$, but not cultivar, regarding percent injury in the soil-based bioassay (Table 5). No injury was observed until $1000 \mathrm{~g}$ a.i./ha rate of $S$-metolachlor was applied, which resulted in $10 \%$ injury $10 \mathrm{~d}$ after treatment in both cultivars.

\section{Discussion}

The hydroponics assay was able to discriminate between a known $S$-metolachlortolerant and -sensitive cultivar within $10 \mathrm{~d}$ based on crop injury data. Comparatively, the soil-based greenhouse assay was not able to distinguish between the two cultivars in $10 \mathrm{~d}$. Surprisingly, maximum root length could not be used as a variable to access tolerance to $S$ metolachlor in hydroponics. This contrasts with previous studies that used hydroponics to screen for dinitroaniline herbicide response on roots of annual bluegrass (Poa annua L.) (Brosnan et al., 2014; Cutulle et al., 2009). However, dinitroanilines act by inhibiting mitosis of roots and typically are not translocated throughout the plant (Appleby and Valverde, 1989). $S$-metolachlor is a very long-chain fatty acid inhibitor, and previous studies with sugar beet (Beta vulgaris) in hydroponics show those varieties that were more tolerant to metolachlor had less translocation of $S$-metolachlor from roots to

Table 4. Impact of herbicide rate on fresh weight for two sweetpotato cultivars taken $10 \mathrm{~d}$ after transplanting in the hydroponics assay.

\begin{tabular}{llc}
\hline Herbicide rate $(\mathrm{mm})$ & Cultivar & Fresh wt $(\mathrm{g})^{\mathrm{z}}$ \\
\hline 0 & Centennial & $19.2 \mathrm{a}$ \\
0 & Beauregard & $18.3 \mathrm{a}$ \\
0.01 & Centennial & $19.9 \mathrm{a}$ \\
0.01 & Beauregard & $15.2 \mathrm{a}$ \\
0.1 & Centennial & $17.0 \mathrm{a}$ \\
0.1 & Beauregard & $12.0 \mathrm{a}$ \\
1.0 & Centennial & $16.4 \mathrm{a}$ \\
1.0 & Beauregard & $17.7 \mathrm{a}$ \\
10 & Centennial & $16.8 \mathrm{a}$ \\
10 & Beauregard & $13.4 \mathrm{a}$ \\
\hline
\end{tabular}

${ }^{\mathrm{z}}$ Mean separation using Tukey's test $(P \leq 0.05)$ Means within a column followed by the same letter grouping are not significantly different.

Table 5. Impact of herbicide and sweetpotato variety on percent injury $10 \mathrm{~d}$ after treatment into native soil pots.

\begin{tabular}{lcc}
\hline $\begin{array}{l}\text { Herbicide } \\
\text { rate }\end{array}$ & $\begin{array}{c}\text { Centennial } \\
\text { percent injury }\end{array}$ & $\begin{array}{c}\text { Beauregard } \\
\text { injury }\end{array}$ \\
\hline 10 & $0 \mathrm{~b}$ & $0 \mathrm{~b}$ \\
100 & $0 \mathrm{~b}$ & $0 \mathrm{~b}$ \\
1000 & $10 \mathrm{a}$ & $10 \mathrm{a}$ \\
\hline
\end{tabular}

${ }^{\mathrm{z}}$ Mean separation using Tukey's test $(P \leq 0.05)$. Means within a column followed by the same letter grouping are not significantly different. shoots (Bollman et al., 2008). Most of the injury symptoms in the sensitive sugar beets from that trial consisted of necrosis or epinasty of the leaves.

\section{Conclusions}

General phytotoxicity was the best variable to use to discriminate between known $S$-metolachlor-tolerant and -sensitive sweetpotato cultivars and is justified by what was observed with $S$-metolachlor in the sugar beet hydroponic assay (Bollman et al., 2008). $S$ metolachlor is absorbed more readily by plant roots than the hypocotyl; therefore, if tolerance is based on reduced translocation, then a hydroponics assay would be a very accurate way to screen sweetpotato germplasm when using general phytotoxicity as the dependent variable. Ultimately, field trials are necessary to validate the potential commercialization of new sweetpotato lines. This hydroponics assay provides a robust preliminary screening for $S$-metolachlor tolerance before field trials.

\section{Literature Cited}

Appleby, A.P. and B.E. Valverde. 1989. Behavior of dinitroanilines in plants. Weed Technol. 3:198-206.

Bollman, S.L., C.L. Sprague, and D. Penner. 2008. Physiological basis for tolerance of sugarbeet varieties to $S$-metolachlor and dimethenamidP. Weed Sci. 56:18-25.

Brosnan, J.T., E.H. Reasor, J.J. Vargas, G.K. Breeden, D.A. Kopsell, M.A. Cutulle, and T.C. Mueller. 2014. A putative prodiamine-resistant annual bluegrass (Pоа аппиа) population is controlled by indaziflam. Weed Sci. 62:138-144.

Cutulle, M.A., J.S. McElroy, R.W. Milwood, J.C. Sorochan, and C.N. Stewart. 2009. Selection of bioassay method influences detection of annual bluegrass resistance to mitotic- inhibiting herbicides. Crop Sci. 49:1088-1095.

Gottschalk, P.G. and J.R. Dunn. 2005. The five parameter logistic: A characterization and comparison with the four-parameter logistic. Anal. Biochem. 343:54-65.

Hoagland, D.R. and D.I. Arnon. 1950. The water culture method for growing plants without soil. Circ. 347. California Agr. Exp. Stn., Berkeley, CA.

Kemble, J. 2020. Southeastern U.S. 2020 vegetable crop handbook.

Meyers, S.L., K.M. Jennings, and D.W. Monks. 2012. Response of sweetpotato cultivars to $S$-metolachlor rate and application time. Weed Technol. 26:474-479.

Meyers, S.L., K.M. Jennings, J.R. Schultheis, and D.W. Monks. 2010. Evaluation of flumioxazin and $S$-metolachlor rate and timing for Palmer amaranth (Amaranthus palmeri) control in sweetpotato. Weed Technol. 24:495-503.

Meyers, S.L. and M.W. Shankle. 2015. Interference of yellow nutsedge (Cyperus esculentus) in 'Beauregard' sweet potato (Ipomoea batatas). Weed Technol. 29:854-860.

Meyers, S.L. and M.S. Shankle. 2017. An evaluation of metam-potassium and $S$-metolachlor PRE for yellow nutsedge management in sweetpotato. Weed Technol. 31:436-440.

Paine, C., T.R. Marthews, D.R. Vogt, D. Purves, M. Rees, A. Hector, and L.A. Turnball. 2012. How to fit nonlinear plant growth models and calculate growth rates: An update for ecologists. Methods Ecol. Evol. 3:245-256. 
Sakhanokho, H.F. and R.Y. Kelley. 2009. Influence of salicylic acid on in vitro propagation and salt tolerance in Hibiscus acetosella and Hibiscus moscheutos (cv 'Luna Red'). Afr. J. Biotechnol. 8:1474-1481.

Seefeldt, S.S., J.E. Jensen, and E.P. Fuerst. 1995. Log-logistic analysis of herbicide dose-response relationships. Weed Technol. 9:218-227.

Smith, S.C., K.M. Jennings, D.W. Monks, S. Chaudhari, J.R. Schultheis, and C. RebergHorton. 2020. Critical timing of Palmer am- aranth (Amaranthus palmeri) removal in sweetpotato. Weed Technol. doi: 10.1017/ wet.2020.1.

U.S. Department of Agriculture. 2019. 2018 State agriculture overview. U.S. Department of Agriculture, Washington, $\mathrm{DC}$.

Wadl, P.A., B.A. Olukolu, S.E. Branham, R.L. Jarrett, C.G. Yencho, and D.M. Jackson. 2018. Genetic diversity and population structure of the USDA sweetpotato. Front. Plant Sci. doi 10.3389/fpls.2018.01166.
Washington Post. 2019. Sweet corn out, sweet potatoes in: Data shows fundamental shifts in American farming. July 2019. <https:// www.washingtonpost.com/business/2019/04/ 20/sweet-corn-out-sweet-potatoes-data-showsfundamental-shifts-american-farming/?fbclid= IwAR2-krrQ_pDCNdSurebyrx0CHEybRvQ AQK6zaKCABUXoguJYn6seTvXRk6Y>

Weir, B. 2001. Sweetpotato research trials: Research progress report. Univ. of California Coop. Ext. 